\title{
Susceptibility of Small-Diameter Norway Spruce Understory Stumps to Heterobasidion Spore Infection
}

\author{
Tālis Gaitnieks ${ }^{1, *}$, Astra Zal̦uma ${ }^{1}$, Kristīne Kenigsvalde ${ }^{1}$, Dārta Klavina ${ }^{1}$, Indulis Brauners ${ }^{1,2}$ \\ and Tuula Piri ${ }^{3}$ \\ 1 Latvian State Forest Research Institute Silava, Rigas 111, LV-2169 Salaspils, Latvia; \\ astra.zaluma@silava.lv (A.Z.); kristine.kenigsvalde@silava.lv (K.K.); darta.klavina@silava.lv (D.K.); \\ i.brauners@lvm.lv (I.B.) \\ 2 AS “Latvijas valsts meži” Vainodes 1, LV-1004 Riga, Latvia \\ 3 Natural Resources Institute Finland (Luke), Management and Production of Renewable Resources \\ Latokartanonkaari 9, FI-00790 Helsinki, Finland; tuula.piri@luke.fi \\ * Correspondence: talis.gaitnieks@silava.lv; Tel.: +371-264-6373-8
}

Received: 23 May 2019; Accepted: 19 June 2019; Published: 22 June 2019

\begin{abstract}
Heterobasidion spp. cause economically important losses in conifer forests in the Northern Hemisphere, especially in Norway spruce stands. Freshly cut stumps are the main route for Heterobasidion spp. infection. Even small stumps of spruce seedlings are known to be susceptible to spore infection, however, very little is currently known about the susceptibility of small stumps of understory spruce to Heterobasidion spore infection. To determine the frequency of spore infections among stumps of understory trees, we analyzed 756 Norway spruce stumps in eight sample plots in eastern Latvia. Understory trees 35-68 years of age, with a stump diameter of 2-10 cm, were felled 33-48 weeks before sampling. In total, 514 (68\%) of the spruce stumps were infected by Heterobasidion spores. The infection frequency among the plots varied from $56 \%$ to $86 \%$. Both infection frequency and stump surface area occupied by Heterobasidion positively correlated with stump diameter, but neither correlated with the time span elapsed between felling and sampling. Colonization of trees by a competitor fungus, Phlebiopsis gigantea (Fr.) Jülich, was observed in 30 (4\%) of investigated stumps, but did not have any effect on the frequency of Heterobasidion infections. Our data show that Norway spruce stumps can be highly susceptible to Heterobasidion spore infection. In order to control airborne Heterobasidion infections, stump treatment should be considered during the sporulation period of Heterobasidion spp.
\end{abstract}

Keywords: Heterobasidion; spore infection; understory Norway spruce; Phlebiopsis gigantea; Picea abies

\section{Introduction}

Heterobasidion root rot causes considerable silvicultural and economical losses in coniferous forests of the Northern Hemisphere. In Europe alone, the economic losses comprise 500-800 million euros annually [1-3]. Particularly high damage is caused in Norway spruce (Picea abies (L.) Karst.) stands, because Heterobasidion mycelium can extend for 8-11 $\mathrm{m}$ up the stem, decaying the most valuable wood assortments $[4,5]$. In addition to the reduction of timber yield and quality, Heterobasidion root rot is a major cause of growth reduction in Norway spruce stands [6-8]. Heterobasidion root rot also increases the risk of diseased stands to storm damage, due to weakened root systems of infected trees $[9,10]$. In Latvia, Norway spruce covers $17 \%$ of the total forest area [11] and ca. $22 \%$ of spruce trees are decayed [12]. In 40-120-year-old spruce stands, decay volumes comprise 19.7-91.8 $\mathrm{m}^{3} \mathrm{ha}^{-1}$, which corresponds to $6 \%-16 \%$ of the total stand volumes [12]. The most serious damage occurs in fertile soils, mainly on abandoned agricultural lands, where $52 \%$ of spruces are decayed on average [13]. 
In Latvia, as elsewhere in Northern Europe, Heterobasidion root rot on Norway spruce is mainly caused by Heterobasidion parviporum Niemelä \& Korhonen [14,15]. Infection of freshly cut stump surfaces by airborne basidiospores is the major route for Heterobasidion spp. to spread both into previously uninfected stands, and to create new primary infections in already diseased stands. Additionally, residual trees damaged during logging operations may become infected by Heterobasidion spores through open wounds on the roots and stem bases. However, compared to stump surface infection, infection via wounds plays a much less important role in the spread of Heterobasidion root rot [16]. From infected trees and stumps, the fungus expands vegetatively as mycelium through root contacts into neighboring trees, eventually forming disease centers in the tree stand $[1,17]$. To prevent establishment of new Heterobasidion infections, stumps in commercial cuttings are commonly treated with the biological agent Phlebiopsis gigantea (Fr.) Jül or urea [18,19].

Even small-diameter Norway spruce trees growing in the understory of forest stands, may play a significant role in the development and spreading of Heterobasidion root rot via root contacts [20-23], and the susceptibility is most likely related to suppression by the overstory. In Latvia, $54 \%$ of the 258 analyzed understory spruce trees in Myrtillosa forest type were decayed, and 30\% of the decay was caused by Heterobasidion spp. [23]. In Finland, an average of $34 \%-42 \%$ of understory spruce trees were infected by Heterobasidion on sites where overstory spruce trees suffered from Heterobasidion root rot. Identification of Heterobasidion genets showed that the majority of understory spruce trees were vegetatively infected from decayed overstory trees [24,25].

However, data about the susceptibility of small stumps of understory spruce trees to Heterobasidion basidiospore infection are scarce. Several studies carried out in even-aged Norway spruce stands have shown that although the risk of stump infection decreases with decreasing stump diameter, small stumps of young spruce trees (less than $10 \mathrm{~cm}$ in diameter) can also be infected by Heterobasidion spores [26-30]. Moreover, Gunulf et al. [31] demonstrated, with the aid of inoculation experiments, that spruce stumps as small as $2 \mathrm{~cm}$ in diameter are able to transfer the disease to surrounding trees. Suppressed understory trees are typically small-sized and frail, despite their high age. Thus, the stump wood is dense, with narrow growth rings and a higher proportion of heartwood compared to stumps of free-growing, non-suppressed spruce trees of the same size [32]. As yet, no information is available as to whether suppression and low tree vigor have any effect on the susceptibility of tree stumps to primary spore infection.

In Latvia, the annual area of forest stand thinning resulting in understory spruce tree stumps is ca. 44,000 ha. It is still unclear if stump treatment is justified in such thinning. The aim of the present study was to investigate natural stump infection of slow-growing understory spruce trees by Heterobasidion spores. In addition, the abundance of Phlebiopsis gigantea, which is an important competitor of Heterobasidion on the freshly exposed stump tissues, was determined in small understory stumps. We hypothesize that suppressed understory Norway spruce trees are highly susceptible to Heterobasidion basidiospore infection.

\section{Materials and Methods}

The study was carried out during June-August in 2012 and 2013 in the eastern part of Latvia $\left(52^{\circ} 42^{\prime} \mathrm{N} / 25^{\circ} 55^{\prime} \mathrm{E}\right)$. Eight sample plots from 0.5 to 1.5 ha in size were established in seven different stands. The plots were located close to each other, within a radius of $6 \mathrm{~km}$. The stands consisted of monodominant Scots pine (sample plots 4 and 8), Norway spruce (sample plots 3, 5, 6, and 7), and birch (sample plots 1 and 2) in the overstory, and naturally regenerated Norway spruce in the understory. The age of the understory spruce trees varied between 35 and 68 years (Table 1). 
Table 1. Characteristics of sample plots, analyzed stumps and occurrence of Heterobasidion spp./Phlebiopsis gigantea infection.

\begin{tabular}{cccccc}
\hline $\begin{array}{c}\text { Sample Plot } \\
\text { No. }\end{array}$ & $\begin{array}{c}\text { Age of } \\
\text { Trees, Years }\end{array}$ & $\begin{array}{c}\text { Age of Stumps } \\
\text { at Sampling, } \\
\text { Weeks }\end{array}$ & $\begin{array}{c}\text { Number of } \\
\text { Analyzed } \\
\text { Stumps }\end{array}$ & $\begin{array}{c}\text { Mean Stump } \\
\text { Diameter } \\
\text { (Range in } \\
\text { Brackets), cm }\end{array}$ & $\begin{array}{c}\text { Proportion of Infected } \\
\text { Stumps (Heterobasidion/ } \\
\text { P. gigantea), \% }\end{array}$ \\
\hline 1 & 35 & 48 & 112 & $4.7(2.3-9.7)$ & $57.1 / 12.5$ \\
2 & 36 & 39 & 162 & $4.1(1.6-9.9)$ & $61.7 / 3.1$ \\
3 & 67 & 37 & 41 & $4.3(1.8-9.7)$ & $56.1 / 0.0$ \\
4 & 67 & 33 & 89 & $5.5(2.2-9.7)$ & $86.5 / 13.5$ \\
5 & 65 & 34 & 101 & $6.2(1.7-10.4)$ & $76.2 / 1.0$ \\
6 & 64 & 34 & 128 & $6.3(1.9-10.4)$ & $77.3 / 0.7$ \\
7 & 68 & 34 & 58 & $5.5(1.6-9.0)$ & $65.5 / 0.0$ \\
8 & 48 & 33 & 65 & $5.3(1.7-9.9)$ & $56.9 / 0.0$ \\
\hline
\end{tabular}

Healthy looking understory spruce trees (41-164 trees in each sample plot) without any visual stem or crown damage were manually felled by chain saw. Stump diameter varied from 2 to $10 \mathrm{~cm}$. In one sample plot (6), however, there were many decayed stumps and fruit bodies on windthrown spruce trees, indicating the possibility of secondary infection among suppressed trees. The ca. $30-60 \mathrm{~cm}$ high stumps were numbered and marked with plastic bands. To avoid Heterobasidion root infection originating from infected stumps of the previous tree generation, the sample trees were situated at least two meters from old stumps. The stumps of understory trees were sampled after 33-48 weeks by cutting two $2-3 \mathrm{~cm}$ thick disks from the stump surface. The first (top) disc was discarded, and the second disc was taken to the laboratory for further analysis. Sample discs were debarked and washed with a stiff brush under running tap water, put into loosely closed plastic bags, and incubated for 5-7 days at room temperature. After incubation, a plastic grid consisting of $0.49 \mathrm{~cm}^{2}$ squares was fixed onto the lower surface of the disc. Heterobasidion spp. were evaluated in stump cross-sections using a dissection microscope by the occurrence of conidiophores, the presence of $P$. gigantea by orange-brown coloring in the wood, and morphological characteristics of mycelium. If at least one conidiophore of Heterobasidion was visible in a grid square, it was then marked as infected. Subsequently, the area of Heterobasidion spp. infection was calculated by the number of marked grid squares. The area occupied by $P$. gigantea in stump cross-sections was traced onto transparent sheets and measured using a planimeter (PLANIX 10S "Marble", Tamaya, Japan). The relative occupied area of Heterobasidion and P. gigantea was calculated by dividing the area occupied with fungi by the total area of the disc. Heterobasidion was not identified to the species level.

The number of stumps infected by P. gigantea and Heterobasidion were compared using a chi-square test. Linear model (binomial regression) was used to analyze the influence of tree age, age of stumps at sampling, stump diameter, and presence of P. gigantea occurrence on the area occupied by Heterobasidion. Individual effects of the same parameters on the area occupied by P. gigantea were also analyzed. In the case of occurrence, binomial regression (logit link function) was used. Model assumptions were verified by graphical inspection. Correlations between stump diameter and area occupied by both fungi and infection frequency were calculated. Statistical analyses were performed in R Studio (R Core Team 2015).

\section{Results}

In all eight sample plots, stumps of understory spruce trees were infected by Heterobasidion spores. The infection frequency among the plots varied from $56 \%$ to $86.5 \%$. The proportion of stumps infected by P. gigantea varied from 0 to $13.5 \%$. On three plots, no stumps colonized by P. gigantea were found (Table 1). Of all 756 studied spruce stumps, $68 \%$ were infected by Heterobasidion, and $4 \%$ by P. gigantea (Table 2). The highest infection frequencies of $P$. gigantea were found in a sample plot which was sampled after a longer period compared to other sample plots $(12.5 \%)$, and in a plot where Scots pine was the dominant tree species $(13.5 \%)$. 
Table 2. Characteristics of sampled understory Norway spruce stumps and average infection frequency of Heterobasidion spp. and Phlebiopsis gigantea.

\begin{tabular}{cc}
\hline Mean stand age, years. \pm SD & $56.3 \pm 14.3$ \\
Mean stump age at sampling, weeks \pm SD & $36.5 \pm 5.1$ \\
Total number of stumps & 756 \\
Mean stump diameter \pm SD, cm. & $5.2 \pm 2.1$ \\
Number of infected stumps (Heterobasidion spp./P. gigantea) & $515 / 33$ \\
Infection frequency Heterobasidion spp. /P. gigantea, $\%$ & $68 / 4$ \\
Stump area occupied by Heterobasidion, $\mathrm{cm}^{2}$. Mean \pm SD & $5.8 \pm 5.5$ \\
Mean stump area occupied by P. gigantea, $\mathrm{cm}^{2} \pm \mathrm{SD}$ & $3.3 \pm 5.0$ \\
\hline
\end{tabular}

There were no problems with model verification. Residuals were independent and lacked any trends. Individual effects of tree age, age of stumps at sampling, stump diameter, and presence of P. gigantea on occurrence, as well as on area of Heterobasidion infection were analyzed.

No correlation was found between the area occupied by P. gigantea and Heterobasidion $(r=0.08$, $p=0.67)$. Neither the age of the tree nor the age of the stump, i.e., the time span elapsed between cutting and sampling, had any effect on the frequency of Heterobasidion ( $p>0.05$ ) (Table 3).

Table 3. Regression analysis summary for individual effects of parameters on occurrence of Heterobasidion. $r^{2}=0.20$; SEM, standard error of the mean.

\begin{tabular}{lcccc}
\hline \multicolumn{1}{c}{ Parameter } & Estimate & SEM & z & P \\
\hline Intercept & -0.77 & 1.40 & -0.55 & -0.58 \\
Stump diameter, cm & 0.65 & 0.06 & 10.55 & $<0.01$ \\
Age of stumps at sampling, weeks & -0.03 & 0.03 & -1.31 & 0.19 \\
Age of trees, years & -0.01 & 0.01 & -0.54 & 0.59 \\
Occurrence of $P$. gigantea & 0.86 & 0.56 & 1.54 & 0.12 \\
\hline
\end{tabular}

Infection frequency of stumps by Heterobasidion and P. gigantea increased with increasing stump diameter (Figure 1). In the case of Heterobasidion infections, however, the correlation was not linear. Among the smallest stumps, $2-6 \mathrm{~cm}$ in diameter, the proportion of infected stumps increased sharply with increasing stump diameter.

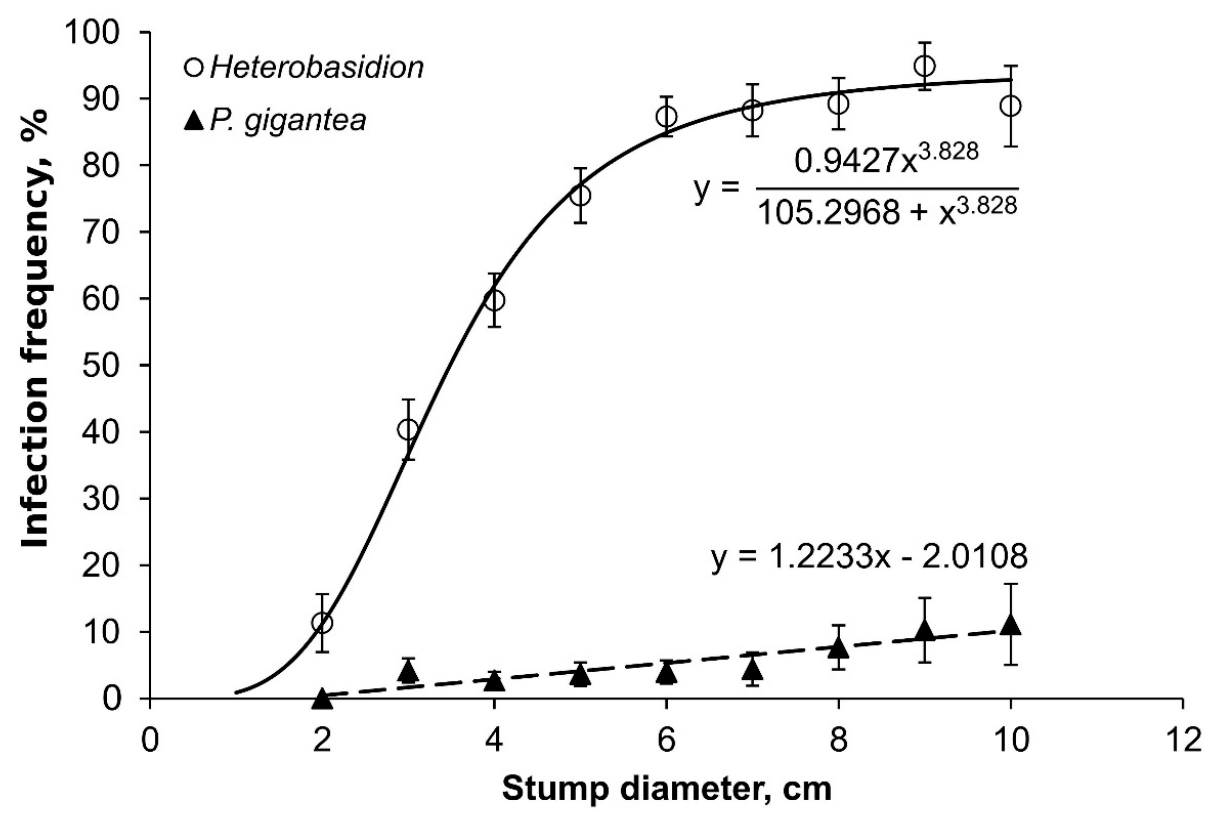

Figure 1. Heterobasidion and Phlebiopsis gigantea infection frequency of suppressed trees in relation to stump diameter. Heterobasidion $r=0.95 ; p<0.001$. P. gigantea $r=0.91, p<0.001$. 
The stump area occupied by Heterobasidion and P. gigantea increased with stump diameter; the increase for Heterobasidion was significant $(r=0.61, p<0.001)$ (Figure 2).

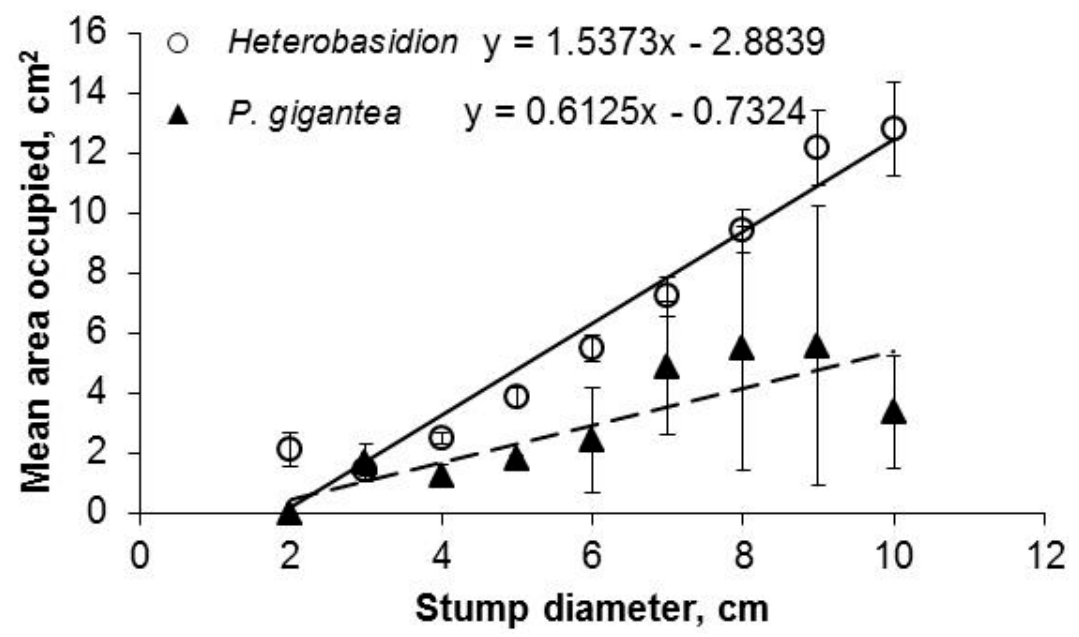

Figure 2. Mean stump area occupied by Heterobasidion and Phlebiopsis gigantea in stump cross-sections cut from suppressed spruce stumps in relation to stump diameter.

The area occupied by Heterobasidion decreased with the age of stumps at time of sampling $(p<0.01$; Table 4).

Table 4. Regression analysis summary for individual effects of parameters on area occupied by Heterobasidion. $\mathrm{r} 2=0.63$; SEM, standard error of the mean.

\begin{tabular}{ccccc}
\hline Parameter & Estimate & SEM & $\mathbf{t}$ & $\mathbf{P}$ \\
\hline Intercept & 0.39 & 0.17 & 2.30 & 0.02 \\
Age of stumps at sampling, weeks & -0.01 & 0.01 & -2.54 & 0.01 \\
Stump diameter, cm & 0.10 & 0.01 & 16.02 & $<0.01$ \\
Age of trees, years & -0.01 & 0.01 & -0.24 & 0.81 \\
\hline
\end{tabular}

The area occupied by $P$. gigantea increased with increasing age of trees $(p=0.01)$; the age of stumps at time of sampling had no effect on the area occupied $(p=0.10)$ (Table 5).

Table 5. Regression analysis summary for individual effects of parameters on area occupied by Phlebiopsis gigantea. $\mathrm{r} 2=0.19 ; \mathrm{SEM}$, standard error of the mean.

\begin{tabular}{ccccc}
\hline Parameter & Estimate & SEM & $\mathbf{t}$ & $\mathbf{P}$ \\
\hline Intercept & -4.6 & 2.37 & -1.94 & 0.06 \\
Age of stumps at sampling, weeks & 0.06 & 0.04 & 1.68 & 0.10 \\
Stump diameter, cm & 0.01 & 0.06 & 0.03 & 0.98 \\
Age of trees, years & 0.04 & 0.02 & 2.73 & 0.01 \\
\hline
\end{tabular}

\section{Discussion}

Conifer stumps resulting from tree felling during the period when Heterobasidion spores are released are optimal targets for primary spore infection and contribute to the spread of Heterobasidion root rot in residual forest stands [1]. The amount of airborne Heterobasidion inoculum at the time of tree felling is the most crucial factor determining the incidence of infection and percentage of stump surface area colonized [33-35]. In the present study, no quantitative measure of spore deposit was performed. However, the high infection rates indicate that the airborne spore concentrations were sufficiently high to cause infections of small-diameter stumps. In Latvia, the high-risk season for Heterobasidion infection is, on average, 6 months in length [36]. 
In addition to availability of spore inoculum, stump size is an important factor influencing success of stump infection; the bigger the stump, the higher the risk of spore infection [37]. The positive correlation between stump diameter and proportion of infected stumps was also apparent in our study. However, the relationship between stump diameter and infection frequency was more pronounced among the smallest stumps with a diameter of less than $6 \mathrm{~cm}$. When stump diameter exceeded $6 \mathrm{~cm}$, the infection frequency was high, over $80 \%$, and not affected by stump diameter. A similar result was reported in a young Norway spruce plantation in Denmark, where the proportion of infected stumps stabilized at over $80 \%$ when stump diameter was above $8 \mathrm{~cm}$ [27].

To our best knowledge, there are no previous studies focused on the susceptibility of small stumps of suppressed understory spruce trees to Heterobasidion spore infection. However, several investigations have reported the infection frequency of small stumps of non-suppressed spruce trees resulting from pre-commercial thinning in even-aged Norway spruce stands. In Denmark, approximately 65\% of the stumps of planted non-suppressed spruce trees with stump diameters between 2 and $10 \mathrm{~cm}$ were infected by Heterobasidion spores four years after cutting [27]. In Sweden, the proportion of infected spruce stumps has been somewhat lower, such that on average, 55\% of Norway spruce stumps 2.4-14.4 $\mathrm{cm}$ in diameter were infected by Heterobasidion spores after two months [30]. In late pre-commercial thinning of Norway spruce, the frequency of Heterobasidion spore infection of spruce stumps in size classes 5-6.9, 7-8.9, and 9-10.9 cm, was ca. 39\%, 59\%, and 67\%, respectively [29]. In Latvia, an average of $25 \%$ of Norway spruce stumps (diameter of 2-12 cm) were infected by Heterobasidion spores [31]. In comparison to these reports, the infection frequency in our study-where an average of $68 \%$ of small, suppressed spruce stumps less than $11 \mathrm{~cm}$ in diameter were infected-appears to be higher than the infection frequency of non-suppressed spruce trees of similar size. Although the stump infection rates in the present and previously mentioned studies are not fully comparable due to possible differences in environmental conditions, as well as in the spore load of both Heterobasidion and competitive fungi at the time of cutting, our study shows that stumps of suppressed spruce trees might be extremely prone to Heterobasidion infection. Unfortunately, no stumps of free-growing, non-suppressed spruce trees were available in our experimental stands to compare stump infection rates between suppressed and non-suppressed spruce trees under the same conditions.

Stump infection by Heterobasidion spores is also affected by wood properties, including wood moisture content. Moisture of the stump wood might be a critical factor determining whether sapwood, heartwood, or the border zone between them is the most favorable area for successful spore infection [37-39]. In our study, the age of understory trees at the time of cutting varied from 35 to 68 years and contained heartwood, despite their small size. In the studied stumps, Heterobasidion infections were particularly confined to the boundary between sapwood and heartwood, where the moisture conditions were evidently most favorable for Heterobasidion spores to germinate [9,38]. It is not known whether small spruce stumps containing exclusively moist sapwood are equally vulnerable to spore infection under the same external conditions. In young planted spruce trees, the moist juvenile wood might restrict the successful establishment of Heterobasidion infection [40]. In addition, inoculation experiments on Sitka spruce have shown that after cutting, stump heartwood remains susceptible to Heterobasidion spore infection longer than sapwood [41]. Thus, stumps of suppressed trees might be predisposed to spore infection for a longer time after felling compared to stumps of free-growing spruce trees. Under different environmental conditions, however, the situation may be different. Under drier external conditions, moister sapwood in free-growing trees may be more favorable for spore infection than drier heartwood.

In contrast, Gunulf et al. [32] found that the probability of spore infection was higher in small Norway spruce stumps with wider year rings, compared to stumps of the same size with narrower year rings. This would indicate that small stumps of slow-growing understory spruce trees would be less susceptible to Heterobasidion spore infection than stumps of fast-growing dominant or co-dominant trees. In addition, Morrison [42] and Gibbs et al. [43] reported that large diameter trees with wide growth rings were more susceptible to Heterobasidion spore infection. The reason that our results do not 
necessarily support these findings may be due to the previously mentioned differences in the external conditions affecting stump moisture and therefore infectivity of stump wood.

Stump size affects not only the success of stump infection but also the subsequent spread of Heterobasidion mycelia to surrounding trees. The potential for secondary expansion of Heterobasidion increases with increasing stump diameter [44]. In small-sized stumps, it is very likely that the proportion of infected stumps will decrease over time [45-47], and some of the stumps may desiccate before the fungus infects adjacent trees. Although occurrence of heartwood in Norway spruce stumps may not be a prerequisite for secondary spread of Heterobasidion mycelium from stump to tree [32], heartwood is the preferred growth substrate for Heterobasidion mycelium in spruce wood [48,49]. Thus, heartwood formed in suppressed trees may facilitate the secondary spread of Heterobasidion. Moreover, the clonal studies carried out in Finland have shown that transfer of Heterobasidion root rot from tree to tree can have a significant role in spreading disease in dense groups of suppressed understory spruce trees [26].

Both the primary infection and the development of Heterobasidion are significantly affected by P. gigantea, which is also a primary colonizer of conifer stumps [34,50]. In our study, the average infection frequency of $P$. gigantea among analyzed stumps was low (only $4 \%$ ), as well as the area occupied by $P$. gigantea $\left(3.3 \mathrm{~cm}^{2}\right)$. Similar results have been obtained in Sweden [51], where the average area occupied by $P$. gigantea after 9 months was $4 \mathrm{~cm}^{2}$ in stands with heavy Heterobasidion infection $(60 \%$ in one stand and $100 \%$ in two other stands). Research in Latvia has shown that P. gigantea affected the development of Heterobasidion in spruce stumps if the area covered by P. gigantea was more than $10 \%$ stump surface area [52]. It is evident that in our study, the incidence of Heterobasidion spore infection was not significantly limited by natural competition by P. gigantea.

\section{Conclusions}

The results of our study indicate that small-diameter stumps of suppressed understory spruce trees are highly susceptible to Heterobasidion spore infection, possibly even more susceptible than stumps of free growing spruce trees of the same size. Thus, small understory stumps may play a significant role in the development of Heterobasidion root rot in naturally regenerated Norway spruce forests. However, further studies are needed to determine to what extent the small stumps are able to transfer disease into the residual trees. Under Latvian conditions, natural infection of understory stumps by $P$. gigantea was not sufficient to reduce Heterobasidion infections. According to our results and evidence currently available, artificial stump treatment with $P$. gigantea or urea in cuttings of understory spruce trees during the sporulation period of Heterobasidion spp. seems to be necessary, especially to prevent spread of Heterobasidion root rot into previously healthy Norway spruce sites.

Author Contributions: Conceptualization, T.G., T.P. and I.B.; methodology, I.B. and T.G.; formal analysis K.K.; investigation, A.Z. and K.K.; data curation, A.Z., K.K. and D.K. writing-original draft preparation, D.K., I.B., K.K., A.Z. and T.G.; writing-review and editing, T.G. and T.P.; supervision, T.G.; project administration, K.K. and A.Z.; funding acquisition, T.G.

Funding: This study was made possible by generous funding and support from the JSC Latvian State Forests project No. 5- 5.5_0004_101_16_4 "Investigation of the factors limiting the spread of root rot", Latvian Council of Sciences grant project No. lzp-2018/1-0431 "Investigations on the role of Phlebiopsis gigantea in restricting vegetative spread of Heterobasidion spp. in stumps of Norway spruce and Scots pine", and European Regional Development Fund's Post-doctoral Research project No. 1.1.1.2/VIAA/2/18/298 “Determining the risk of Heterobasidion root-rot and fungal communities in roots of Norway spruce stands on former agricultural land".

Acknowledgments: In addition to the funding sources listed above, we would like to acknowledge the current and past students, LSFRI Silava employees that participated in investigation. We are grateful to each, but special thanks go to Agrita Kenigsvalde, Lauma Bruna as well to Dainis Edgars Rungis for language revision.

Conflicts of Interest: The authors declare no conflict of interest. 


\section{References}

1. Redfern, D.B.; Stenlid, J. Spore dispersal and infection. In Heterobasidion annosum: Biology, Ecology, Impact and Control; Woodward, S., Stenlid, J., Karjalainen, R., Hüttermann, A., Eds.; CAB International: Wallingford, UK, 1998; pp. 105-141.

2. Korhonen, K.; Holdenrieder, O. Neue erkenntnisse über den wurzelschwamm (heterobasidion annosum s.1.). eine literaturübersicht. Forst. Und. Holz. 2005, 60, 206-211.

3. Asiegbu, F.O.; Adomas, A.; Stenlid, J. Conifer root and butt rot caused by Heterobasidion Annosum (Fr.) Bref. s.l. Mol. Plant Pathol. 2005, 6, 395-409. [CrossRef] [PubMed]

4. Stenlid, J.; Wästerlund, I. Estimating the frequency of stem rot in Picea abies using an increment borer. Scand. J. Forest. Res. 1986, 1, 303-308. [CrossRef]

5. Vasiliauskas, R.; Stenlid, J. Spread of S and P group isolates of Heterobasidion annosum within and among Picea abies trees in central Lithuania. Can. J. For. Res. 1998, 28, 961-966. [CrossRef]

6. Tamminen, P. Butt rot in Norway spruce in Southern Finland. Commun. Inst. For. Fenn. 1985, 127, 1-52.

7. Bendz-Hellgren, M.; Stenlid, J. Long-term reduction in the diameter growth of butt rot affected Norway spruce, Picea abies. For. Ecol. Manag. 1995, 74, 239-243. [CrossRef]

8. Bendz-Hellgren, M.; Stenlid, J. Decreased volume growth of Picea abies in response to Heterobasidion annosum infection. Can. J. For. Res. 1997, 27, 1519-1524. [CrossRef]

9. Bendz-Hellgren, M.; Lipponen, K.; Solheim, H.; Thomsen, I.M. The nordic countries. In Heterobasidion annosum: Biology, Ecology, Impact and Control; Woodward, S., Stenlid, J., Karjalainen, R., Hüttermann, A., Eds.; CAB International: Wallingford, UK, 1998; pp. 333-345.

10. Oliva, J.; Samils, N.; Johansson, U.; Bendz-Hellgren, M.; Stenlid, J. Urea treatment reduced Heterobasidion annosum s.l. root rot in Picea abies after 15 years. For. Ecol. Manag. 2008, 7, 2876-2882. [CrossRef]

11. Klavina, D.; Menkis, A.; Gaitnieks, T.; Velmala, S.; Lazdins, A.; Rajala, T.; Pennanen, T. Analysis of Norway spruce dieback phenomenon in Latvia-A belowground perspective. Scand. J. Forest. Res. 2016, 31, $156-165$. [CrossRef]

12. Arhipova, N.; Gaitnieks, T.; Donis, J.; Stenlid, J.; Vasaitis, R. Butt rot incidence, causal fungi and related yield loss in Picea abies stands of Latvia. Can. J. For. Res. 2011, 41, 2337-2345. [CrossRef]

13. Gaitnieks, T.; Šica, L.; Indriksons, A.; Grantina, L. Root-rot detection in Norway spruce stands using pulsed electronic tool. In Proceedings of the 11th International Conference Root and Butt Rots of Forest Trees, Poznan - Bialowieza, Poland, 16-22 August 2004; pp. 379-385.

14. Korhonen, K.; Bobko, I.; Hanso, S.; Piri, T.; Vasilauskas, A. Intersterility groups of Heterobasidion annosum in some spruce and pine stands in Byelorussia, Lithuania and Estonia. Eur. J. Plant Pathol. 1992, 22, $384-392$. [CrossRef]

15. Korhonen, K.; Piri, T. The main hosts and distribution of the $\mathrm{S}$ and $\mathrm{P}$ groups of Heterobasidion annosum in Finland. In Proceedings of the 8th IUFRO Conference on Root and Butt Rots, Wik, Sweden and Haikko, Finland, 9-16 August 1993; Johansson, M., Stenlid, J., Eds.; Swedish University of Agricultural Sciences: Uppsala, Sweden, 1994; pp. 260-268.

16. Isomäki, A.; Kallio, T. Consequences of injury caused by timber harvesting machines on the growth and decay of spruce (Picea abies (L.) Karst.). Acta For. Fenn. 1974, 136, 1-25. [CrossRef]

17. Stenlid, J.; Redfern, D.B. Spread within the tree and stand. In Heterobasidion annosum: Biology, Ecology, Impact and Control; Woodward, S., Stenlid, J., Karjalainen, R., Hüttermann, A., Eds.; CAB International: Wallingford, UK, 1998; pp. 125-141.

18. Korhonen, K. Simulated stump treatment experiments for monitoring the efficacy of Phlebiopsis gigantea against Heterobasidion. Root and butt rots of forest trees. In Proceedings of the 10th International Conference on Root and Butt Rots, Québec, QC, Canada, 16-22 September 2003; Laflamme, G., Bérubé, J.A., Bussiéres, G., Eds.; Canadian Forest Service: Chalk River, ON, Canada, 2003; pp. 206-210.

19. Thor, M. Optional stump treatment against Heterobasidion annosum in European forestry-Current situation. In Proceedings of the 10th International Conference on Root and Butt Rots, Québec, QC, Canada, 16-22 September 2003; Laflamme, G., Bérubé, J.A., Bussiéres, G., Eds.; Canadian Forest Service: Chalk River, ON, Canada, 2003; pp. 170-175.

20. Semenkova, I.G. Attack of spruce understory by Heterobasidion annosum. Nauchn. Tr. Mosk. Lesotek. Inst. 1971, 38, 150-166. 
21. Schönhar, S. Untersuchungen über die infection der fichte (Picea abies Karst.) durch Heterobasidion Annosum (Fr.) Bref. Allgemeine Forst-Und Jagdzeitung 1995, 166, 14-17.

22. Piri, T. Early development of root rot in young Norway spruce planted on sites infected by Heterobasidion in Southern Finland. Can. J. For. Res. 2003, 33, 604-611. [CrossRef]

23. Gruduls, K.; Gaitnieks, T.; Donis, J.; Liepa, I. Heterobasidion spp. in Picea abies understory: Incidence and impact on radial growth of trees. Res. For. 2012, 2, 21-24.

24. Piri, T.; Korhonen, K. Infection of advance regeneration of Norway spruce by Heterobasidion parviporum. Can. J. For. Res. 2001, 31, 937-942. [CrossRef]

25. Piri, T.; Valkonen, S. Incidence and spread of Heterobasidion root rot in uneven-aged Norway spruce stands. Can. J. For. Res. 2013, 43, 872-877. [CrossRef]

26. Paludan, F. Infection and spread of Fomes annosus in young Norway spruce. Det Forstl. Forsøgsvæs. Dan. 1966, 30, 21-47.

27. Solheim, H. Infeksjon av rotkjuke på granstubber til ulike årstider og effekten av ureabehandling. Nor. Inst. Skogforsk. Rapp. Skogforsk 1994, 3, 1-10.

28. Berglund, M.; Carlsson, T.; Rönnberg, J. Infection of Heterobasidion spp. in late pre-commercial thinnings of Picea abies in southern Sweden. In Proceedings of the 12th International Conference on Root and Butt Rots, Berkeley, California, Medford, OR, USA, 12-19 August 2007; Garbelotto, M., Gonthier, P., Eds.; The University of California: Berkeley, CA, USA, 2008; pp. 221-225.

29. Gunulf, A.; Mc Carthy, R.; Rönnberg, J. Control efficacy of stump treatment and influence of stump height on natural spore infection by Heterobasidion spp. of precommercial thinning stumps of Norway spruce and birch. Silva Fenn. 2012, 46, 655-665. [CrossRef]

30. Gaitnieks, T.; Brauners, I.; Kenigsvalde, K.; Zalıuma, A.; Brūna, L.; Jansons, J.; Burneviča, N.; Lazdin̦š, A.; Vasaitis, R. Infection of pre-commercially cut stumps of Picea abies and Pinus sylvestris by Heterobasidion spp.-A comparative study. Silva Fenn. 2018, 52. [CrossRef]

31. Gunulf, A.; Wang, L.; Englund, J.E.; Rönnberg, J. Secondary spread of Heterobasidion parviporum from small Norway spruce stumps to adjacent trees. Forest Ecol. Manag. 2013, 287, 1-8. [CrossRef]

32. Sellin, A. Sapwood amount in Picea abies (L.) Karst. determined by tree age and radial growth rate. Holzforschung 1996, 50, 291-296. [CrossRef]

33. Rishbeth, J. Dispersal of Fomes annosus Fr. and Peniophora gigantea (Fr.) Massee. Trans. Br. Mycol. Soc. 1959, 42, 243-260. [CrossRef]

34. Yde-Andersen, A. Seasonal incidence of stump infection in Norway spruce by air-borne Fomes annosus spores. For. Sci. 1962, 8, 98-103.

35. Stenlid, J. Homokaryotic Heterobasidion annosum mycelia in stumps of Norway spruce. In Proceedings of the 8th IUFRO Conference on Root and Butt Rots, Wik, Sweden and Haikko, Finland, 9-16 August 1993; Johansson, M., Stenlid, J., Eds.; Swedish University of Agricultural Sciences: Uppsala, Sweden, 1994; pp. 243-248.

36. Brauners, I.; Brūna, L.; Gaitnieks, T. Testing the 'Rotstop' biological preparation for controlling Heterobasidion root rot in Latvia. Res. Rural Dev. 2014, 2, 97-102.

37. Bendz-Hellgren, M.; Stenlid, J. Effects of clear-cutting, thinning, and wood moisture content on the susceptibility of Norway spruce stumps to Heterobasidion annosum. Can. J. For. Res. 1998, 28, 759-765. [CrossRef]

38. Swedjemark, G.; Stenlid, J. Population dynamics of the root rot fungus Heterobasidion annosum following thinning of Picea abies. Oikos 1993, 66, 247-254. [CrossRef]

39. Redfern, D.B. The effect of wood moisture on infection of Sitka spruce stumps by basidiospores of Heterobasidion annosum. Eur. J. Forest Pathol. 1993, 23, 218-235. [CrossRef]

40. Vollbrecht, G.; Gemmel, P.; Pettersson, N. The effect of precommercial thinning on the incidence of Heterobasidion annosum in planted Picea abies. Scand. J. Forest. Res. 1995, 10, 37-41. [CrossRef]

41. Woods, C.M.; Woodward, S.; Redfern, D.B. Receptivity of Picea sitchensis stumps to infection by Heterobasidion annosum basidiospores. Forestry 2000, 73, 457-465. [CrossRef]

42. Morrison, D.J. Factors affecting infection of precommercial thinning stumps by Heterobasidion annosum in coastal British Columbia. In Proceedings of the Symposium on Research and Management of Annosus Root Disease (Heterobasidion annosum) in Western North America, Monterey, CA, USA, 18-21 April 1989; Otrosina, W.J., Scharpf, R.F., Eds.; Forest Service, Berkeley, Canada: Toronto, ON, Canada, 1989; pp. 95-100. 
43. Gibbs, J.N.; Greig, B.J.W.; Pratt, J.E. Fomes root rot in Thetford Forest, East Anglia: Past, present and future. Forestry 2002, 75, 191-202. [CrossRef]

44. Piri, T. The spreading of the $\mathrm{S}$ type of Heterobasidion annosum from Norway spruce stumps to the subsequent tree stand. Eur. J. Forest Pathol. 1996, 26, 193-204. [CrossRef]

45. Schönhar, S. Fungal red-rot in Norway spruce trees damaged during log extraction. Allg. Forst-Und Jagt-Ztg. 1975, 146, 72-75.

46. Berglund, M.; Rönnberg, J. Effectiveness of treatment of Norway spruce stumps with Phlebiopsis gigantea at different rates of coverage for the control of Heterobasidion. For. Pathol. 2004, 34, 233-243. [CrossRef]

47. Morrison, D.J.; Johnson, A.L.S. Stump colonization and spread of Fomes annosus 5 years after thinning. Can. J. For. Res. 1978, 8, 177-180. [CrossRef]

48. Redfern, D.B.; Pratt, J.E.; Gregory, S.C.; MacAskill, G. Natural infection of Sitka spruce thinning stumps in Britain by spores of Heterobasidion annosum and long-term survival of the fungus. Forestry 2001, 74, 53-72. [CrossRef]

49. Oliva, J.; Bernat, M.; Stenlid, J. Heartwood stump colonisation by Heterobasidion parviporum and H. annosum s.s. in Norway spruce (Picea abies) stands. For. Ecol. Manag. 2013, 295, 1-10. [CrossRef]

50. Meredith, D.S. Further observations on fungi inhabiting pine stumps. Ann. Bot. 1960, 24, 63-78. [CrossRef]

51. Berglund, M.; Rönnberg, J.; Holmer, L.; Stenlid, J. Comparison of five strains of Phlebiopsis gigantea and two Trichoderma formulations for treatment against natural Heterobasidion spore infections on Norway spruce stumps. Scand. J. Forest. Res. 2005, 20, 12-17. [CrossRef]

52. Kenigsvalde, K.; Brauners, I.; Korhonen, K.; Zaluma, A.; Mihailova, A.; Gaitnieks, T. Evaluation of the biological control agent Rotstop in controlling the infection of spruce and pine stumps by Heterobasidion in Latvia. Scand. J. Forest. Res. 2016, 31, 254-261. [CrossRef]

(C) 2019 by the authors. Licensee MDPI, Basel, Switzerland. This article is an open access article distributed under the terms and conditions of the Creative Commons Attribution (CC BY) license (http://creativecommons.org/licenses/by/4.0/). 